InOedia $\begin{aligned} & \text { InMedia } \\ & \text { The French Journal of Media Studies }\end{aligned}$

9.1. $\mid 2021$

Film and TV-induced Tourism: Some Contemporary

Aspects and Perspectives

\title{
Beyond Aesthetics: Hollywood Studios, Financial Incentives and Film-induced Tourism
}

Joseph Armando Soba

\section{(2) OpenEdition \\ Journals}

Electronic version

URL: https://journals.openedition.org/inmedia/2929

DOI: $10.4000 /$ inmedia.2929

ISSN: 2259-4728

Publisher

Center for Research on the English-Speaking World (CREW)

Electronic reference

Joseph Armando Soba, "Beyond Aesthetics: Hollywood Studios, Financial Incentives and Film-induced Tourism", InMedia [Online], 9.1. | 2021, Online since 15 January 2022, connection on 08 February 2022. URL: http://journals.openedition.org/inmedia/2929 ; DOI: https://doi.org/10.4000/inmedia.2929

This text was automatically generated on 8 February 2022.

(c) InMedia 


\title{
Beyond Aesthetics: Hollywood Studios, Financial Incentives and Film-induced Tourism
}

\author{
Joseph Armando Soba
}

When the Colorado Film Commission was founded in July $1969,{ }^{1}$ it was entirely unthinkable that the film studios solidly anchored in California and New York City would chase after the financial incentives offered by second-order film production centres in the United States. Nevertheless, by 1984, 44 American states and 60 cities $^{2}$ had established Film Commissions to woo movie and television productions. Local authorities thought that their localities could obtain a share of the budget spent by the studios at filming locations. In association with tourist offices, these film offices have played an active role in promoting movie locations and fostering film-induced tourism. Twenty-six years later, in 2010, the 40 American states with motion picture programmes granted studios a total of $\$ 1,396,000,000^{3}$ in tax incentives. To refute any misuse of those subsidies, the Motion Picture Association of America (MPAA) published a press release in 2016 asserting that the film and television industries generated $\$ 50$ billion in wages and supported nearly 305,000 direct jobs in the United States. ${ }^{4}$

Substantial academic research on film-induced tourism has been published since the 1990s. Riley and Van Doren (1992), Riley, Baker and Van Doren (1998) analyse how movies induce people to travel to filming sites, while Busby and Klug (2001) focus on the difficulties of measuring the impact of media-induced tourism. Not only does Beeton (2006 and 2008) examine the way movies can be instrumental in marketing destinations, but she also foregrounds the tourism based on the visit of film studios. Hudson and Ritchie (2006) explore the marketing strategies used to promote shooting locations, while Donald and Gammack (2007) show how films can be crucial to making localities more visible to the audience. Other researchers, such as Macionis and Sparks (2009), analyse the different motivations that bring tourists to the locations depicted in movies. Hudson, Wang, and Moreno-Gil (2011) study how film commissions and tourism industry attract movie productions. Grenier (2011), Lizotte and Grenier (2011), Vergopoulos and Bourgatte (2011) underline the relationship between fans and movie- 
induced tourism and the increased competition between cities and countries to develop local film industry. Although this scholarship analyses film-induced tourism and its impact as well as the marketing strategies of filming localities, the link between filminduced tourism and financial incentives offered to Hollywood studios remains understudied. Likewise, research on film subsidies carried out by Grand, (2006) Christopherson and Rightor (2010) Malyshev (2010), Bordman (2018), and many other scholars do not examine movie-induced tourism.

Though Louisiana's tax credit scheme has been analysed by Liu, Kolenda, Fitzpatrick and Todd (2010), Mayer (2017), Miller (2017) and Joseph (2018), these researchers pay little attention to its connection with film-motivated tourism, and mainly evaluate its economic benefits. Reports prepared for different public bodies in Louisiana, which assess the various impacts of film tax credits on the state, including film-induced tourism, are valuable primary sources for this work. Among them are Economics Research Associates (2009), Tim Mathis (2012), HR\&A Advisors, Inc. (2015), Loren C. Scott \& Associates, Inc. (2017), Market Dynamics Research Group (2012 and 2018), and Camoin Associates, Inc. (2019 and 2021).

Given that Louisiana was the first state to create a Motion Picture Production Tax Credit Program in the United States in 1992, and the programme was one of the most generous from 2002 to 2017, it constitutes a relevant case study for a better understanding of the relationship between public incentives and film-induced tourism. The main objective of this paper is to analyse the extent to which Louisiana has benefited from movie-induced tourism as a result of its financial efforts to lure Hollywood studios to shoot on location in the state. Since the launch of its tax incentives, Louisiana has hosted the production of many blockbusters and Academy award-winning movies, such as Ray (Taylor Hackford, 2004), The Curious Case of Benjamin Button (David Fincher, 2008), The Fantastic Flying Books of Mr. Morris Lessmore (William Joyce, 2011), Dallas Buyers Club (Jean Marc Vallée, 2013), 12 Years a Slave (Steve McQueen, 2013), Green Book (Peter Farrelly, 2018). Moreover, the thriving local film industry stimulated the emergence of film tours and attractions like New Orleans Movie \& TV Tours and Duck Commander Tour. This article begins with a brief outline of Louisiana's Motion Picture Investor Tax Credit Program before exploring the role of film offices, tourist offices and private companies in attracting movie-induced tourists in the state. Lastly, it discusses the impact of television series and film-induced tourism in Louisiana.

\section{Louisiana, the Pioneer of State Film Subsidies}

In 1992, Louisiana rolled out a film subsidy programme by enacting the Motion Picture Incentive Act (LA R.S. 47:6007) which went into effect on January 1, 1993. The primary objective of the law was "to encourage development in Louisiana of a strong capital and infrastructure base for motion picture production in order to achieve an independent, self-supporting industry [...] attract private investment for the production of motion pictures in Louisiana." ${ }^{5}$ To reach this goal the local authorities sought to lower production costs for Hollywood studios and thus give the state a comparative advantage over its competitors. The first programme was primarily designed to cover the potential losses of films and television series. It allowed any movie production 
company shooting in Louisiana to claim an income tax credit of 50 to $70 \%$ for losses due to bad investments, if a studio spent between $\$ 2,000,000$ and $\$ 25,000,000$. ${ }^{6}$

The subsidy programme was intended to be a strong incentive for film production since the studios were subsidised in case of financial failure. In return, Louisiana could benefit from the money production companies and their staff might spend in the state.

Nevertheless, the studios did not find the scheme attractive because it focused on unsuccessful investments. Indeed, the companies seek tax rebates on their investments rather than protection from financial losses. By the end of the 1990s, Louisiana's tax credit, though a novelty in the United States at that time, had faded away. It could not compete with the Canadian Film or Video Production Tax Credit (CPTC) and Film or Video Production Services Tax Credit (PSTC) set up by the Canadian federal and provincial governments in 1995 and 1997.

Louisiana amended its legislation in 2002, 2003 and 2005 to address the studios' concerns and to allow a tax credit for investment rather than losses incurred on investments. Instead of subsidising a production company only when its movie does not make any profit, according to the new laws, the amount of the financial incentive allocated to the studios was determined by the level of their investments in the state, and the money spent on wages for employees who reside in Louisiana.

Even if movie-motivated tourism is not among the priorities of the programme, it constitutes what John Grand called "collateral benefits" because of its indirect economic impact on the filming locations as further demonstrated below. Thanks to the 2005 change in legislation (LA R.S. 47:6007), studios could claim a 10\% income tax credit for every dollar invested provided that the amount totalled at least $\$ 300,000$. It increased to $15 \%$ if a movie company could demonstrate that its investments in the state exceeded $\$ 8,000,000$. In 2006 , the state raised the tax credit to $25 \%$ of investment and offered an extra $10 \%$ if the studios could prove that they had spent a large proportion of their investments on hiring local staff. ${ }^{8}$ Table 1 summarises the economic impact of Louisiana's Motion Picture Production Tax Credit Program during the first years of its implementation, from 2002 to 2007.

\begin{tabular}{|l|l|l|l|l|l|l|}
\hline Year & 2002 & 2003 & 2004 & 2005 & 2006 & 2007 \\
\hline Productions* & 1 & 15 & 32 & 36 & 47 & 65 \\
\hline $\begin{array}{l}\text { Tax incentives } \\
\text { (million USD) }\end{array}$ & $\mathrm{n} / \mathrm{a}^{* *}$ & $\mathrm{n} / \mathrm{a}$ & $\mathrm{n} / \mathrm{a}$ & 66.3 & 87.6 & 115.1 \\
\hline Overall spending within the state (million USD) & 4.0 & 92.3 & 158.3 & 238.6 & 293.4 & 317.1 \\
\hline Number of jobs created & & & & & & \\
\hline Direct & 516 & 993 & 1,281 & 1,870 & 2,350 & 2,450 \\
\hline Indirect & $\mathrm{n} / \mathrm{a}$ & $\mathrm{n} / \mathrm{a}$ & $\mathrm{n} / \mathrm{a}$ & 1,110 & 1,390 & 1,450 \\
\hline Induced & $\mathrm{n} / \mathrm{a}$ & $\mathrm{n} / \mathrm{a}$ & $\mathrm{n} / \mathrm{a}$ & 540 & 680 & 710 \\
\hline
\end{tabular}


Table 1 - Tax Incentives, Spending, and Jobs in Louisiana

* The productions mentioned in the table include feature films, made for television movies and television series.

** n/a: not available

Sources: Economics Research Associates, "Louisiana Motion Picture, Sound Recording and Digital Media Industries," Prepared for the State of Louisiana, Louisiana Economic Development (2009): 29; $32 ; 33 ; 35$.

The change in the legislation in 2002 brought a substantial increase of productions in 2003 and 2004. The amendments made to the programme in 2005 brought about a sharp rise of productions in 2006 and 2007. Furthermore, the number of jobs created and the spending in Louisiana by production companies increased steadily from 2003 to 2007. This is probably related to films like All the King's Men (Steven Zaillian, 2006), starring such famous actors as Sean Penn, Jude Law and Anthony Hopkins; Déjà Vu (Tony Scott, 2006), starring Denzel Washington, Paula Patton and Val Kilmer. The Curious Case of Benjamin Button (David Fincher, 2008), shot in New Orleans in 2006 and 2007, illustrates the financial effort of Louisiana to lure stars of Brad Pitt's prestige, as well as majors like Paramount Pictures and Warner Bros Pictures. These studios received $\$ 27,117,737$ in tax incentives to cover part of the movie budget estimated at $\$ 167$ million. ${ }^{9}$

The correlation between the film subsidies and the increase of production cannot be questioned since the number of movies shot in the state and the studios' investments had steadily grown with the change in the legislation and the tax credit programme. Although tax credit schemes had mushroomed in the United States in the 2000s, with more than 40 states and Puerto Rico competing to offer bigger and better subsidies, Louisiana's programme remained one of the most generous because its:

film tax credits are 'transferrable' and 'refundable'. That means any tax not used by a production company earning the credit - either because the company's Louisiana tax liability is less than the amount of the credits earned, or because the company owes no state income tax - may be transferred to another Louisiana taxpayer. Corporations or individuals that buy the credits can use them to offset their state tax liability. Unused credits can be sold directly to the state for 85 percent of their original value. ${ }^{10}$

The advantages of the Louisiana movie tax credits over those implemented in other states reside in the fact that the studios benefit from direct cash rebates if their expenses are eligible for subsidies. The production companies are subsidised through different ways. They can receive a check from the Louisiana Department of Revenue, or they can transfer and even sell the credits awarded by the state to any local taxpayer who will use them to pay for their taxes. Besides, since 2002, the programme has contributed to the emergence of film industry-specific infrastructure and postproduction facilities. Three studios-Second Line Stages, Celtic Media, and Millennium-successful service providers such as Hollywood Trucks LLC ${ }^{11}$ (a Louisianabased company that provides trucks, talent, and trailers to film companies), Cast and Crew Entertainment Services, MBS equipment, Turnkey Accommodations, Napper Law, CAT Entertainment Services, Camera Division, and Post Digital, ${ }^{12}$ to name only a few major ones, have all sprouted up.

According to Louisiana's Motion Picture Production Tax Credit Program, enacted on July 1, 2017, its long-term objectives are to "encourage [...] increased global competitiveness with other states in fully utilizing economic development options within the motion picture industry." ${ }^{13}$ The new programme seems promising if one considers the success of such movies as Green Book (Peter Farrelly, 2018) and Greyhound 
(Aaron Schneider, 2020). Filmed in and around New Orleans, Green Book won in 2019 three Academy Awards: for Best picture, for Best Supporting Actor and for Best Original Screenplay. Among many other awards, Green Book also won the Golden Globe Award for Best Motion Picture - Musical or Comedy. At the $93^{\text {rd }}$ Academy Awards (April 2021), Greyhound, starring Tom Hanks, and filmed in Baton Rouge was nominated for Best sound. Moreover, in April 2021, it won the Golden Reel Award for Outstanding Achievement in Sound Editing - Sound Effects and Foley for Feature Film. Table 2 presents an overview of tax incentives, spending, jobs and earnings from 2017 to 2020 .

\begin{tabular}{|c|c|c|c|c|}
\hline Year & 2017 & 2018 & 2019 & 2020 \\
\hline Tax incentives & $\$ 113,185,209$ & $\$ 148,401,444$ & $\$ 175,781,104$ & $\$ 132,804,928$ \\
\hline \multicolumn{5}{|c|}{ Overall spending within the state } \\
\hline Direct & $\$ 342,073,398$ & $\$ 446,840,575$ & $\$ 538,472,660$ & $\$ 429,591,440$ \\
\hline Indirect & $\$ 351,981,965$ & $\$ 479,631,595$ & $\$ 218,419,193$ & $\$ 178,172,259$ \\
\hline Induced & $n / a^{*}$ & $n / a^{*}$ & $\$ 259,647,458$ & $\$ 205,423,542$ \\
\hline Total & $\$ 694,055,363$ & $\$ 926,472,170$ & $\$ 1,016,539,310$ & $\$ 813,187,241$ \\
\hline \multicolumn{5}{|c|}{ Number of jobs created } \\
\hline Direct & 2,095 & 2,446 & 4,834 & 4,695 \\
\hline Indirect & 3,562 & 4,770 & 2,795 & 2,693 \\
\hline Induced & $n / a^{*}$ & $n / a^{*}$ & 2,435 & 2,249 \\
\hline Total & 5,657 & 7,216 & 10,064 & 9,636 \\
\hline \multicolumn{5}{|l|}{ Earnings } \\
\hline Direct & $\$ 108,138,006$ & $\$ 148,428,853$ & $\$ 167,507,104$ & $\$ 157,669,410$ \\
\hline Indirect & $\$ 130,292,734$ & $\$ 177,313,263$ & $\$ 86,991,190$ & $\$ 84,266,860$ \\
\hline Induced & $n / a^{*}$ & $n / a^{*}$ & $\$ 103,618,734$ & $\$ 96,463,268$ \\
\hline Total & $\$ 238,430,740$ & $\$ 325,742,116$ & $\$ 358,117,028$ & $\$ 338,399,538$ \\
\hline
\end{tabular}

Table 2 - Tax Incentives, Spending, Jobs, and Earnings in Louisiana

* n/a: not available

Sources: Camoin Associates, Inc. "Economic and Fiscal Impact of Louisiana Entertainment Tax Credits," (2019): 6; 9.

Camoin Associates, Inc. "Economic and Fiscal Impact. Motion Picture Production Tax Credits, 2019-2020," (2021): 4; 8. 
Although the tax incentives have been limited to $\$ 150$ million per fiscal year since 2017, the programme remains generous, providing up to a $40 \%$ tax credit with a minimum of $25 \%{ }^{14}$ The companies can claim a $5 \%$ increase for productions shot outside New Orleans. When comparing tax incentives with spending certified by Louisiana Economic Development, the return on investment is substantial. Indeed, from 2017 to 2020 , the spending of production companies and the earnings of staff exceed incentives by far. Besides, taking advantage of popular movies shot in the state, Louisiana's public bodies not only entice Hollywood studios to their localities, but they tend to turn the audiences into future visitors of locations featured in these movies and television productions.

\section{Seducing Media-Related Tourists}

New Orleans, the largest city in Louisiana, is very active in attracting and retaining film producers. Film New Orleans (FNO), an office for film and video specifically designed as a one-stop shop for movie professionals, operates under the authority of the Mayor's Office of Cultural Economy ${ }^{15}$. Apart from acting as the service provider for film producers, FNO has collaborated with the former New Orleans Tourism and Marketing Corporation (NOTMC), ${ }^{16}$ another city agency. NOTMC was providing funding for the film office to liaise movie producers in order to promote official Carnival festivities. NOTMC also advertised film projects as well as shooting locations. In May 2012, it launched GO NOLA, a tourism application for the City of New Orleans. GO NOLA ${ }^{17}$ is a kind of trip organiser that helps tourists to plan their travels and visits. It provides upto-date information on filming locations, places to eat, shop, listen to music and stay. The application uses film stars' voices to guide tourists throughout New Orleans. Wendell Pierce's voice, star of Treme (2010-2013, HBO), guides visitors in the Treme neighbourhood and recommends them to visit places featured in the television series.

Similarly, through its "Feed Your Soul" promotion campaign, the Louisiana Office of Tourism intensifies advertising around films and television series made in Louisiana. Their website named "Louisiana Travel," advertises movies and television shows. A section entitled "Louisiana on the Silver Screen and Small Screen," ${ }^{18}$ entirely dedicated to features and television series, presents more than 500 productions shot in the state. The list ranges from the oldest movies dating back to the silent film era, such as Tarzan of the Apes (Scott Sidney, 1918), to classical movies such as A Streetcar Named Desire (Elia Kazan, 1951), to Easy Rider (Dennis Hopper, 1969) and the comedy-drama The Big Easy (Jim McBride, 1986), all the way up to more recent films Django Unchained (Quentin Tarantino, 2012), 12 Years a Slave (Steve McQueen, 2013), Green Book (Peter Farrelly, 2018), and Greyhound (Aaron Schneider, 2020). The website also highlights successful television series, including Treme (2010-2013, HBO), True Blood (2008-2014, HBO), and NCIS: New Orleans (2014-2021, CBS). ${ }^{19}$

Although 12 Years a Slave (Steve McQueen, 2013), is not a documentary film meant to promote Louisiana's historic sites, the state is taking advantage of its popularity to advertise the localities where it was filmed. Since its three Academy Awards (Best Picture, Best Adapted Screenplay, and Best Supporting Actress) and the Golden Globe Award for Best Motion Picture - Drama contribute to boost the popularity of this film shot in New Orleans and at some historic homes in the southeast of the state, the Louisiana Travel website recommends tourists to visit its filming sites and other places. 
In fact, the "Northup Trail" ${ }^{20}$ promotes the places where the main character, Solomon Northup, spent his time in slavery and where he gained his freedom.

The Louisiana Travel website ${ }^{21}$ complements both tourist guides and travel guides by providing visitors with beautiful pictures, views of filming sites and interactive maps. In that sense, it anticipates some visitors' needs at an early stage by proposing, through internet marketing, tours related to films and television shows. Louisiana Travel website also offers online visitors the opportunity to have an interactive experience with filming locations while they explore the city and its various cultural offerings. While presenting the television series Treme, the website suggests visiting the French Quarter, eating and drinking at Rock ' $\mathrm{N}$ ' Bowl on Carrolton, listening to live jazz at Vaughn's Lounge, having dinner "in the historic setting of Dooky Chase's Restaurant" and tasting some beignets and coffee at Café Du Monde. ${ }^{22}$

By providing online visitors with details of previous films and television productions along with testimonials, the website also becomes a tourist guide persuading visitors to include shooting sites in their travel plans and even recommending what they should do and see in the state. Apart from proposing accommodation, restaurants and other information, the website prompts tourists to visit and discover what their television or movie heroes experienced. This helps to influence the tourists' desires by guiding their choices from the initial stages when they browse the Louisiana Travel website.

Alongside the website of the Louisiana Office of Tourism, a business called New Orleans Movie \& TV Tours (NOLA Movie Tours) was founded in 2011 to take advantage of the film activities that have flourished in the state. According to Jonathan Ray, the owner and founder of NOLA Movie Tours, the idea to create his business dated back to when he had the opportunity to spend time watching the shooting of the romantic comedy $A$ Little Bit of Heaven (Nicole Kassell, 2011) and the action thriller The Mechanic (Simon West, 2011). For Jonathan Ray, NOLA Movie Tours is appealing to film-induced tourists because "watching the entire movie making process was such an experience, that I decided that I wanted to share it with everyone that visits New Orleans [...] To see a location where your favorite movie was shot or a famous actor strolled is a huge thrill for movie fans." ${ }^{23}$

Edgar Morin in Les stars (1984) shows how film stars can be a source of imitation and inspiration. Likewise, Richard Dyer in Stars (1999) analyses how audience/star relationships can lead to a degree of identification whereby some people need to imitate their favourite stars. The phenomena studied by Morin and Dyer can explain why film and television series stars tend to be instrumental in seducing tourists. As movie stars have been shown to induce consumption of goods and identification to specific situations, some viewers, filmgoers and fans wish to visit the shooting locations to experience feelings similar to their favourite characters. With respect to this, some popular films or television series become motivational tool of tourism destinations for movie-induced tourists.

At the beginning (April 2011), NOLA Movie Tours focused only on older films and television series. However, starting in 2013, Jonathan Ray accessed new and popular productions that reach a large television audience, such as American Horror Story (2011, FX) and NCIS: New Orleans (2014-2021, CBS). These successful productions not only increased the number of attractions proposed to the public, but also boosted the visitors' interest in taking part in the daily tour. This certainly explains why a report prepared for the Louisiana Film and Entertainment Association and the Motion Picture 
Association of America, Inc. (MPAA) by HR\&A Advisors, and published in 2015 depicts NOLA Movie Tours as a thriving enterprise ${ }^{24}$. NOLA Movie Tours organises two daily tours that last two hours each, one in the morning and the second in the afternoon. In 2019 , the tour cost $\$ 43$ for adults and $\$ 29$ for children between 4 and 12 years old. ${ }^{25}$ In April 2019, the figures regarding the number of visitors were not available on the website, yet the calendar showed that more than half of the tours in May and June 2019 had been sold out two months in advance. However, in December 2021, updated information and prices were not accessible ${ }^{26}$.

In addition, Duck Dynasty (2012-2017), a reality television show, filmed at the Duck Commander warehouse and offices in West Monroe, Louisiana, is also used to advertise the sights and sites of the city, as well as the banks of the Ouachita River and Bayou Desiard. The filming locations of the reality television series around the Monroe and West Monroe area have become a major tourist attraction. The show and state's success story began with the premiere of season one in spring $2012^{27}$ on A\&E cable television, which concluded as the most watched show on the network with $6,500,000$ viewers. The premiere of season four, still airing on A\&E on August 14, 2013, totalled 11,800,000 or so viewers. This represents an increase of $37 \%$ compared to the season three premiere. As 6,300,000 viewers aged 25-54 watched the episode broadcast that night, Duck Dynasty set a record among adults for the most watched nonfiction series telecast in cable television history. Moreover, the same year, the show became the top-rated reality programme on cable.

With such an impressive television success, which occurred a few months after season four premiered, Duck Dynasty turned into a popular and powerful brand for merchandising across the United States. Clare O'Connor, a staff writer at Forbes, noted that:

By the end of 2013, Duck Dynasty product tie-ins will have raked in a massive $\$ 400$ million in revenues according to industry sources. Sales in Walmart alone account for about half of that bounty, with some stores devoting entire aisles to Robertsonthemed merchandise [...] At Walmart's annual shareholders conference in June, the retail giant announced that their bestselling piece of apparel across every category over the past year - men's, women's and children's - was Duck Dynasty graphic tshirt. $^{28}$

The screen success of Duck Dynasty seems to be correlated with the commercial success of Duck Dynasty paraphernalia, the impact of the television series on the American audience being evidenced by the popularity of its merchandising. Furthermore, the sales of Duck Dynasty products, the televisual success of the series, and the Duck Commander Tour have turned the Monroe and West Monroe areas into far more attractive places for the viewership of the reality show. Since then, Duck Dynasty has become a crucial driver of media-induced tourism for West Monroe. The Monroe-West Monroe Convention and Visitors Bureau created the Official Duck Commander Hometown Tour to take advantage of the popularity engendered by the television show. The tour includes a brochure and a mobile website that features more than 40 locations seen during the first four seasons. Viewers familiar with Duck Dynasty remember filming locations such as Art Nails and Spa, Haskell's Donuts, the Corner Coffee House, West Monroe Police Department, or Twin City Pawn Shop. As these locations are sorted in alphabetical order, ${ }^{29}$ tourists and fans of the show flocking to the Monroe and West Monroe areas can thus easily find their favourites. 
Even though Courtney Hornsby, president of the West Monroe-West Ouachita Chamber of Commerce, does not provide any official figures on the number of tourists brought in by Duck Dynasty, she was convinced that "the town of 13,000 is inundated on weekends. And local businesses are aiming to take advantage of the Duck Dynasty crowds." 30 Rebekah Landry, art and social media director of Landry Vineyards, confirmed Hornsby's assertion. She strongly believed that their family business benefits from the show, and estimated that half the visitors come by because of Duck Dynasty. ${ }^{31}$ Indeed, Landry Vineyards, featured in the "Sauvignon Beard" episode in season one of the reality show in 2012, was included in the Duck Commander Tour. The family's vineyard also has a tasting room open every Saturday and by appointment during the week. The Landry Vineyards offer the visitors a great variety of activities, ${ }^{32}$ ranging from concerts with live music to tractor tours of the vineyard and Cajun cuisine.

According to a report published in 2014 and prepared by the Hospitality Research Center of the University of New Orleans for the Louisiana Department of Culture, Recreation and Tourism, "hotel rooms sold and capacity also grew in 2013. Over the last year, Monroe added new hotel capacity ( $2 \%$ increase), and successfully sold the new hotel rooms (5\% increase). ${ }^{33}$ In the case of Monroe and West Monroe, the connection between media-motivated tourism and the growing number of visitors in the filming sites is indisputable. The flow of visitors in the shooting locations has subsequently led to the increase in the number of hotel rooms available for rent, a testament to the impact of Duck Dynasty's televisual and commercial success on the local economy. Monroe and West Monroe embody the kind of return on investment the Louisiana authorities have been pursuing when they established the Motion Picture Production Tax Credit Program.

Duck Dynasty is not an isolated case, since many other movies and television series shot in Louisiana attract tourists in the filming locations, and Steel Magnolias (Herbert Ross, 1989) is one of them. Steel Magnolias "was premiered in November 1989 after completion of filming in Natchitoches, LA. Based on three data sources collected since 1980, the Natchitoches Parish Tourism Commission reported a 39.7\% increase in visitors for 1990." ${ }^{34}$ In their work, Riley and Van Doren (1992); and Riley, Baker and Van Doren (1998) demonstrated that Natchitoches is a vivid example of a filming location transformed into a successful attraction for tourists. Indeed, since 1990, the Steel Magnolias Tour of Filming Sites ${ }^{35}$ has provided the city and its surrounding areas with long-term tourism opportunities.

Having watched sites and scenes on the screen, a growing number of people feel a strong desire to experience these shooting locations. Louisiana Travel and Louisiana Destinations websites, NOLA Movie and Tours as well as New Orleans \& Company represent valuable assets for the development of media-related tourism in the state. Owing to their capabilities to sell the destinations to the potential visitors, these tourism promotion entities and websites constitute powerful tools for the commodification of filming sites.

\section{Impact of Television Shows and Film-Related Tourism: A Debatable Issue?}

Louisiana is a relevant vantage point to examine the impact of television series and film-induced tourism in the United States since it has developed a pervasive marketing 
strategy and presence online via advertising, both of which strongly link tourism to the motion picture and television industries. Moreover, from 2002 to 2017, Louisiana implemented one of the most generous tax credit programmes since the amount of credits administered by the Office of Entertainment Industry within the Louisiana Economic Development each fiscal year had no fixed limit, while the California Film Commission allocated a maximum of $\$ 100$ million each fiscal year. ${ }^{36}$ The main aims pursued by these uncapped financial incentives were to attract Hollywood studios, develop the Louisiana film industry, and produce beneficial multiplier effects within the state as well as increase investments and employment growth in a wide range of economic sectors.

After years of investments, in 2013 the state was able to become the first film production centre in the world, outpacing California. In 2013, Louisiana hosted 18 films ${ }^{37}$ out of the 108 films produced in the world by major Hollywood companies, whereas California and Canada shared the second and third positions with 15 movies each respectively, and the United Kingdom was home to the shooting of 12 films. Supporting the 18 films cost $\$ 230$ million in tax incentives. ${ }^{38}$ These figures exemplify the results of the hard-driving policy of film incentives implemented during more than a decade.

From 2002 to 2012, Louisiana paid a high price for these outcomes since it "spent more than $\$ 1$ billion on subsidies to film production." 39 In 2017, following a change in the legislation (LA R.S. 46:6007) that limits the total film tax credit to $\$ 150$ million per fiscal year, the state granted studios $\$ 113$ million in $2017, \$ 148$ million in $2018^{40}$ and nearly $\$ 133$ million in $2020 .{ }^{41}$ Through these measures, government officials expect to gain not only promotional advantages but also direct and indirect economic impact, such as the increase in the number of tourists to filming sites and other attractions. According to a report prepared in 2020 by Camoin Associates for Louisiana Entertainment, the Office of Entertainment Industry Development of the Louisiana Department of Economic Development, the Motion Picture Production Tax Credit Program generated certified spending estimated at $\$ 538$ million in 2019 and $\$ 429$ in 2020. The film production spending supported 4,834 direct jobs in 2019 and 4,695 jobs in $2020^{42}$. If one judges the return on investment, the direct economic impact for the state by far outweighs the cost of financial incentives to studios. Such results explain why government officials have been maintaining the subsidies to the film industry since their first implementation in 1992, although the law was amended many times.

With respect to this, Louisiana Lieutenant Governor Jay Dardenne asserted, "I know many of our visitors to Louisiana are here because of the exposure we have received on television and as the preferred location for more feature films than anywhere in North America. This industry is also a perfect fit for the creative culture in Louisiana, which we enjoy, and of which we are so proud." ${ }^{43}$ The certified spending and the growing number of productions shot in the state demonstrate the impact of subsidies on the local economy. Further, since the staff working in the film industry spend their wages on goods and services, this spending makes other economic sectors thrive, generate additional employment, new income, and tax receipts. This move is supposed to fuel a virtuous circle of economic growth within the state. Nonetheless, it is more difficult to provide undisputable figures on film-induced tourism to support Jay Dardenne's contention. Indeed, evaluating the exact share of tourists ascribed to film-motivated tourism in hotel occupancy, recreation, food industry and any other form of 
consumption in large cities like Baton Rouge and New Orleans is not an easy task. Tourism promotion bodies in Natchitoches where Steel Magnolias was filmed, as well as in Monroe and West Monroe for Duck Dynasty, can easily assess the impact of filminduced tourism on their localities, while this is not the case for bigger cities.

Over the last ten years, many studies and reports commissioned by Louisiana Entertainment, the Louisiana Department of Culture, Recreation and Tourism, the Louisiana Budget Project and the Louisiana Film and Entertainment Association have analysed the state's film and television industries. Most of the reports focus on the benefits and the costs of the motion picture tax credits and the global impact of tourists' spending trends. They also evaluate the direct and indirect economic effects of the local film and television industries on tourism. Nevertheless, they do not show whether movies and television series actually influenced tourists' decisions to visit specific cities or filming sites. Only two of these reports have added a survey targeting tourists to the economic data collected and their fiscal analysis. In 2014, HR\&A Advisors, Inc., a consulting firm providing services for real estate companies, conducted the first survey; in 2018, MDRG, a market research group, organised the second one. Both reports concluded that the challenge consists in evaluating accurately the role of movies and television shows in the decision of tourists to travel to Louisiana, except for some popular productions. For HR\&A Advisors report, film-motivated tourists influenced by "iconic" productions are easily identifiable, even many years after their premiere, because of their desire to visit the shooting locations that symbolise those famous movies or television series.

In November 2014, HR\&A Advisors, Inc. in partnership with Federated Sample, a Louisiana-based market research company specialised in programmatic sampling, audience and impact measurement developed an online survey which targeted a panel of 1,500 United States residents aged 18 or over who had visited Louisiana in 2012 and 2013. It focused to a certain extent on the respondents' awareness of films, television shows, and documentaries shot in Louisiana that depict the state's landscapes. ${ }^{44}$ The survey had 10 out of 20 questions related to movies, television shows, and documentaries or to activities and visits directly linked to productions filmed in the state. These enabled the survey to detect whether the respondents' awareness of films and television productions had affected their decision to travel to Louisiana and discover its landscapes and culture, as well as filming sites.

One survey question listed 21 recent films and television shows featuring Louisiana. As it contained well-known films and television series along with less famous ones, the sample of productions proposed to the respondents was not expected to bias the survey. The respondents also had the option to write in other productions not listed in the sample. The survey mentioned three Academy award-wining movies: The Curious Case of Benjamin Button (David Fincher, 2008; Academy Award for Best Achievement in Art Direction, Academy Award for Best Achievement in Makeup, Academy Award for Best Achievement in Visual Effects); The Fantastic Flying Books of Mr. Morris Lessmore (William Joyce, 2011; Academy Award for Best short film, animated), 12 Years a Slave (Steve McQueen, 2013, Academy Award for Best picture). There were also some popular television productions such as True Blood (2008-2014, HBO's most popular show from 2009 to 2012), Duck Dynasty (2012-2017; the largest audience for a nonfiction series in 2013 telecast on cable television), NCIS: New Orleans (2014-2021; averaged 18,200,000 viewers when it premiered on October 27, 2014). 
HR\&A Advisors, Inc. and Federated Sample received 1,381 responses out of the 1,500 online questionnaires. The results show that $72.0 \%$ of total respondents were aware of productions shot in Louisiana and portraying the state. For the individuals surveyed who visited the state, $57.3 \%$ recognised that this awareness had positively affected their choice to travel to Louisiana. Among all the figures published in the HR\&A report, two demonstrate the extent to which films, television shows, and documentaries can influence the decision of tourists to visit a specific location, monument or historic place. First, $22.9 \%$ of total respondents confirmed that their awareness of Louisiana's audiovisual productions was "very important" to the choice to travel primarily for leisure to the state. Second, $14.5 \%$ of total respondents said films and television series had a "very important" effect on their decision. These individuals also participated in at least one activity related to the film or television show and even extended their stay in Louisiana to further enjoy leisure directly linked to specific productions ${ }^{45}$ These statistics shed light on the proportion of individuals whose decisions were influenced by the fact that films and nonfiction productions had been made there.

The survey conducted by MDRG in March 2018 targeted a sample of 602 people aged 25 or over who had travelled to Louisiana in the preceding twelve months. The main objective of the study was to measure the volume of travel influenced by movies and television shows filmed in Louisiana. The most striking finding was that:

All visitors to Louisiana are highly likely to have visited the New Orleans/ Northshore Area, but those with high viewership of productions filmed and set in Louisiana are more likely to have visited other parts of the state, particularly Central Louisiana. This suggests that high viewership respondents typically visit more areas within the state than those with low viewership. ${ }^{46}$

This implies that the respondents who have seen many films or television series shot in Louisiana and featuring the state have a tendency to visit other localities, not only the filming sites, compared to those who have seen fewer productions. The study shows that long exposure to the movies depicting in an attractive way a state can influence the decisions to visit not only the filming sites, but also other places. It seems that the tourists' interest in Louisiana's actual landscapes, culture, history, and other aspects can be ascribed, to a certain extent, to the films and television series they watched. Indeed, the depictions of Louisiana in films and television series may inspire visits of shooting locations and tourist sites across the state.

The surveys conducted, respectively, by HR\&A Advisors, Inc. and MDRG confirm that films and television series have a certain effect on the decision of the tourists to visit specific places and filming sites. In addition, MDRG report estimated that $\$ 1.3$ billion annual tourism revenue "may be attributable to Louisiana productions." ${ }^{47}$ For the Louisiana Office of Tourism, films and television productions portraying the state in a favourable light constitute advertising that helps to shape its good reputation and increase the number of tourists.

In conclusion, while there is no doubt that fans and tourists interested in television series and films travel to locations where motion pictures have been shot, the impact is more often than not limited to the region depicted in the movie. Government officials do not hesitate to grant Hollywood studios financial incentives for productions because they expect a substantial return on investment and an increased advertising campaign for their states. The rationale for supporting television series and film productions is to fuel the development of local economy, acquire greater visibility, and enhance movie- 
induced tourism. Sometimes states such as Louisiana have a tendency to overestimate and oversell the impact of film-induced tourism to their residents:

Revenue Secretary Kimberly Robinson [...] told reporters that the state expects to release a new economic-impact analysis of the film program next spring that will be more positive in light of changes made to the program in 2017. Robinson said she expects it will show that each $\$ 1$ in incentives generates $\$ 5$ in 'economic activity' in the state. ${ }^{48}$

Kimberly Robinson refers to the change in the legislation enforced in 2017 when Louisiana limited its film incentives to a maximum amount each fiscal year. Controversy over the cost-effectiveness of the film tax credits was recurring because the subsidies were not capped each fiscal year from 2002 to 2017. In comparison with the public funding allocated to Hollywood studios through administrative support and tax rebates, the return on investment was not worth maintaining financial incentives without a fixed amount. This certainly explains why, in 2017, Louisiana amended the legislation on the Motion Picture Production Tax Credit Program (LA R.S. 47:6007) and restricted the maximum amount of tax rebates at $\$ 150$ million per fiscal year.

The existence of film-related tourism is not a contentious issue in the case of Louisiana, nevertheless the entire state does not necessarily benefit from the expenses and the direct or indirect effects of film tourists. The impact of movies and television series on tourism industry is still limited to a small number of motion pictures. Notwithstanding, some famous television series, blockbusters, and movie stars known and admired worldwide will continue to stimulate the further expansion of film-induced tourism.

\section{BIBLIOGRAPHY}

Beeton, Sue. “Understanding Film-Induced Tourism.” Tourism Analysis 11, (October 2006): 181-188. Beeton, Sue. "From the Screen to the Field: The Influence of Film on Tourism and Recreation." Tourism Recreation Research 33, no. 1 (2008): 39-47.

Bordman, Ethan, Y. “Finding 'Hollywood': Using State Film Incentive Programs to Select the Right Location for a Production." New York State Bar Association Entertainment, Arts and Sports Law Journal 29, no 3 (Fall/Winter 2018): 40-46.

Busby, Graham and Klug, Julia. "Movie-induced tourism: The challenge of measurement and other issues." Journal of Vacation Marketing 7, no. 4 (2001): 316-332.

Camoin Associates, Inc. "Economic and Fiscal Impact of Louisiana Entertainment Tax Credits." 2019.

Camoin Associates, Inc. "Economic and Fiscal Impact. Motion Picture Production Tax Credit, 2019-2020." 2021.

Christopherson, Susan and Rightor, Ned. "The Creative Economy as 'Big Business'. Evaluating State Strategies to Lure Film Makers." Journal of Planning Education and Research 29, no. 3 (March 2010): 336-352. 
Donald, Stephanie H. and Gammack, John G. Tourism and the Branded City. Film and Identity on the Pacific Rim, Hampshire: Ashgate Publishing Limited, 2007.

Dyer, Richard. Stars. London: 1979; British Film Institute, 1999.

Economics Research Associates. "Louisiana Motion Picture, Sound Recording and Digital Media Industries.” ERA Project No. 18014, February 2009.

Gjorgievski, Mijalce and Trpkova, Sinolicka Melles. "Movie-Induced Tourism: A New Tourism Phenomenon." UTMS Journal of Economics 3, no. 1 (2012): 97-104.

Grand, John. “Motion Picture Tax Incentives: There's No Business Like Show Business." State Tax Notes (March 13, 2006): 791-803.

Grenier, Alain A. “Ciné-tourisme : du concept au fan, au cœur de l'expérience.” Téoros, Revue de recherche en tourisme, 30, no. 1 (2011): 79-89.

Halstuk, Martin. "The Seduction of Hollywood. States Are Going All Out to Get Movie Makers to Run Away," Los Angeles Times, September 22, 1985.

Henchman, Joseph. “More States Abandon Tax Incentives as Programs' Ineffectiveness Becomes More Apparent.” Tax Foundation 272 (June 2, 2011): 1-4.

Hospitality Research Center. “Louisiana Tourism Forecast: 2014-2017.” Prepared for Louisiana Department of Culture, Recreation and Tourism by the University of New Orleans, April 2014.

Hospitality Research Center. “Louisiana Tourism Forecast: 2015-2018.” Prepared for Louisiana Department of Culture, Recreation and Tourism by the University of New Orleans, April 2015.

HR\&A Advisors, Inc. "Economic Impacts of the Louisiana Motion Picture Investor Tax Credit." Prepared for Louisiana Film and Entertainment Association and Motion Picture Association of America, Inc., April 6, 2015.

Hudson, Simon and Ritchie, Brent J. R. "Promoting Destinations via Film Tourism: An Empirical Identification of Supporting Marketing Initiatives." Journal of Travel Research 44 (May 2006): 387-396.

Hudson, Simon and Wing Sun Tung, Vincent. "Lights, Camera, Action...! Marketing Film Locations to Hollywood." Marketing Intelligence \& Planning 28 no. 2 (2010): 188-205.

Hudson, Simon, Wang, Youcheng and Moreno-Gill, Sergio. "The Influence of a Film on Destination and the Desire to Travel: a Cross-Cultural Comparison." International Journal of Tourism Research 13 (September 2011): 177-190.

Joseph, Robert, G. "Playing the Big: A History of New Orleans in Film and Television." PhD Dissertation submitted to the Graduate College of Bowling Green State University, May 2018.

Karpovich, Angelina, I. “Theoretical Approaches to Film-Motivated Tourism." Tourism and Hospitality Planning \& Development 7, no. 1 (February 2010): 7-20.

Katz, Stephen M. "The Global Success of Production Tax Incentives and the Migration of Feature Film Production from the USA to the World. Year 2005 Production Report." The Center for Entertainment Industry Data and Research, 2006.

Lizotte, Martine et Grenier, Alain, A. "Le nouvel eldorado des destinations touristiques." Téoros, Revue de recherche en tourisme 30, no. 1 (2011): 73-78.

Loren C. Scott \& Associates, Inc. “The Economic Impact of Louisiana's Entertainment Tax Credit Programs for Film, Live Performance \& Sound Recording." Office of Entertainment Industry Development Louisiana Department of Economic Development, April 2017. 
Luther, Claudia. “Hollywood's Dollars Go on Location,” Los Angeles Times, January 8, 1984.

Macionis, Niki and Sparks, Beverly. "Film-Induced Tourism: An Incidental Experience.” Tourism Review International 13 (2009): 93-101.

Malyshev, Alexander. "Financing Film Through Aggressive Tax Incentives. A Losing Propositions for the States?" Media \& law Policy 19, no. 2 (Fall 2010): 229-237.

Mathis, Tim. "Louisiana Film Tax Credits: Costly Giveaways to Hollywood.” A Louisiana Budget Project Report, August 2012.

Mayer, Vicki. Almost Hollywood, Nearly New Orleans. The Lure of Local Film Economy. Oakland: University of California Press, 2017.

Market Dynamics Research Group (MDRG). “Louisiana. Pick Up Your Passion. Perceptions Research Report.” January 16, 2012.

Market Dynamics Research Group (MDRG). "Louisiana Office of Tourism. Effect of Film on Visitation.” Research Report, April 18, 2018.

Medved, Harry. “Commissioners: Hollywood's Would-Be Suitors.” Screen Actor 28, no. 2, (summer 1989): 24-25, 34.

Miller, Jade L. "Louisiana Disguised: Film Tax Incentives and Location Representation in Contemporary Hollywood Films." The Journal of Popular Culture 50, no. 3 (2017): 466-489.

Morin, Edgar. Les stars. Paris: 1957; Galilée, 1984.

Motion Picture Association of America. "The Economic Impact of the Motion Picture and Television Production Industry on the United States, 2006 report." Encino and Washington, DC, MPAA Strategic Planning and Research, January 2007.

Motion Picture Association of America. "The Economic Impact of the Motion Picture and Television Production Industry on the United States." Washington, DC, April 2009.

Motion Picture Association of America. "Evaluating the Effectiveness of State Film Tax Credit Programs. Issues that need to be considered." Prepared by Ernest \& Young and commissioned by the MPAA, 2012.

National Conference of State Legislatures. "State Film Production Incentives \& Programs." Washington, March 28, 2014.

National Conference of State Legislatures. "State Film Production Incentives \& Programs." Washington, January 30, 2018.

Riley, Roger W. and Van Doren, Carlton S. “Movies as Tourism Promotion. A 'Pull' Factor in a 'Push' Location.” Tourism Management (September 1992): 267-274.

Riley Roger, Baker, Dwayne and Van Doren, Carlton S. "Movie Induced Tourism." Annals of Tourism Research 25, no. 4 (1998): 919-935.

Robyn, Mark and David, Harry. "Movie Production Incentives in the Last Frontier." Tax Foundation 199 (April 2012): 1-8.

Thomas, Lynnell L. “'People Want to See What Happened': Treme, Televisual Tourism, and the Racial Remapping of Post-Katrina New Orleans.” Television and New Media 13, no. 3 (2012): 213-224.

Vagionis, Nikolaos and Loumioti, Maria. "Movies as a Tool of Modern Tourist Marketing." Tourismo: An International Multidisciplinary Journal of Tourism 6, no. 2 (Autumn 2011): 353-362. 
Vergopoulos, Hécate and Bourgatte, Michaël. "Le ciné-tourisme comme pratique allographique." Téoros, Revue de recherche en tourisme 30, no. 1 (2011): 99-107.

Yang Liu, Cathy, Kolenda, Ric, Fitzpatrick, Grady and Todd, Tim, N. "Re-creating New Orleans: Driving Development Trough Creativity.” Economic Development Quarterly 24, no. 3 (2010): 261-275.

\section{NOTES}

1. Harry Medved, "Film Commissioners: Hollywood's Would-Be Suitors," Screen Actor, 28, no. 2, (summer 1989): 24.

2. Claudia Luther, “Hollywood's Dollars Go on Location,” Los Angeles Times, January 8, 1984, 1.

3. Joseph Henchman, "More States Abandon Tax Incentives as Programs' Ineffectiveness Becomes More Apparent," Tax Foundation (June 2, 2011): 4.

4. "MPAA analysis refutes 'false and misleading' study on film production incentives by USC Assistant Professor Michael Thom". Press Release, September 14, 2016. https:// www.motionpictures.org/press/mpaa-analysis-refutes-false-and-misleading-study-on-film-

production-incentives-by-usc-assistant-professor-michael-thom/ <accessed on September 19, 2021>.

5. For more information on Louisiana legislation on film Tax credits since the law was enacted. LA R.S. 47:6007, https://www.legis.la.gov/Legis/LawPrint.aspx?d=102363 <accessed on May 19, 2018>.

6. John Grand, "Motion Picture Tax Incentives: There's No Business Like Show Business," State Tax Notes (March 13, 2006): 792.

7. Grand, "Motion Picture Tax Incentives: There's No Business Like Show Business," 796.

8. Grand, "Motion Picture Tax Incentives: There's No Business Like Show Business," 792-793.

9. Michael Cieply,"States' Film Production Incentives Cause Jitters," The New York Times, October 11, 2008. <accessed on November 30, 2021>.

10. Tim Mathis, "Louisiana Film Tax Credits: Costly Giveaways to Hollywood," A Louisiana Budget Project Report, (August 2012): 3.

11. Jennifer Larino, "Hollywood Trucks owner Andre Champagne wins first NOLA.com | The Times-Picayune Excellence in Innovation Award," NOLA.com | The Times-Picayune, March 21, 2015. https://www.nola.com/news/business/article_91207cc8-6e1e-5658-ac01-f7063c0188b9.html $<$ accessed on April 30, 2021>.

12. HR\&A Advisors, Inc., "Economic Impacts of the Louisiana Motion Picture Investor Tax Credit," Prepared for Louisiana Film and Entertainment Association and Motion Picture Association of America, Inc. (April 6, 2015): 9; 19.

13. LA R.S. 47:6007, Louisiana State Legislature, https://www.legis.la.gov/Legis/Law.aspx? $\mathrm{d}=102363<$ accessed on April 21, 2021>.

14. Louisiana Economic Development, "Overview of 2017 Legislative Session changes to the Motion Picture Production Tax Credit Program." (June 30, 2017): 2. https:// www.opportunitylouisiana.com/docs/default-source/incentives-forms-docs/summary-of-2017regular-session-changes-to-film-program_06-30-17-2.pdf?sfvrsn=f3f4a805_2 <accessed on December 5, 2021>.

15. Mayor's Office of Cultural Economy, "Film New Orleans," https://www.filmneworleans.org/ home/ <accessed on May 1, 2021>.

16. In 2020, New Orleans Tourism Marketing Corporation merged with the New Orleans Convention and Visitors Bureau to form the private non-profit tourism entity New Orleans \& Company. Jeff Adelson, "Tourism promotion agency to be remade into cultural funding 
organization under city plan," Nola.com, January 19, 2020, https://www.nola.com/news/ article_df37a1b8-3af9-11ea-8667-6f27ab7ebde8.html <accessed on May 1, 2021>.

17. "New Orleans Tourism Marketing Corporation, NOTMC, Launches GO NOLA, the First Official City Visitor App for iPhone," https://www.neworleans.com/articles/post/new-orleans-tourismmarketing-corporation-notmc-launches-go-nola-the-first-official-city-visitor-app-for-iphone/ $<$ accessed on December 4, 2021>.

18. "Louisiana on the Silver Screen and Small Screen," https://www.louisianatravel.com/ articles/louisiana-silver-screen-small-screen <accessed on October 3, 2021>.

19. "Light. Camera. Louisiana," https://www.louisianatravel.com/film <accessed on September 24, 2021>.

20. "Solomon Northup Trail," https://byways.louisianatravel.com/byway/northup-trail $<$ accessed on October 3, 2021>.

21. "Film in Louisiana," https://www.louisianatravel.com/film <accessed on October 3, 2021>.

22. "Treme," https://www.louisianatravel.com/film-louisiana/treme <accessed on December 4, 2021>.

23. About Jonathan Ray and the short story of his business, "About Us," http:// www.nolamovies.com/what-we-do\#<accessed on September 14, 2021>.

24. HR\&A Advisors, Inc., "Economic Impacts of the Louisiana Motion Picture Investor Tax Credit," 28.

25. NOLA Movies Tours "Frequently Asked Questions," http://www.nolamovies.com/ wwwzervecom/nolamovies <accessed on April 23, 2019>, and <accessed on December 5, 2021>.

26. NOLA Movies Tours "Tours Details," http://www.nolamovies.com/calendar <accessed on April 23, 2019>, and <accessed on December 5, 2021>.

27. "Duck Dynasty Season 4 premiere sets cable record with 11.8 million viewers," Channel Guide Magazine, August 16, 2013. https://www.channelguidemag.com/tv-news/2013/08/16/duckdynasty-season-4-premiere-record-ratings/\#print <accessed on September 15, 2021>.

28. Clare O'Connor, "Duck Dynasty's Brand Bonanza: How A\&E (And Walmart) Turned Camo Into $\$ 400$ million Merchandise Sales," Forbes, November 6, 2013. https://www.forbes.com/sites/ clareoconnor/2013/11/06/duck-dynastys-brand-bonanza-how-ae-and-walmart-turned-camointo-400-million-merchandise-sales/\#4focde351714 <accessed on September 17, 2021>.

29. See Official Duck Commander Tour promoted by Monroe and West Monroe. https:// www.monroe-westmonroe.org/duck-commander-locations.cfm?

id=0\&sort=alpha\&orderby=ascending <accessed on April 26, 2019>.

30. Amy Eley, “'Duck Dynasty' fans flock to West Monroe, La.,” Today, October 16, 2013. https:// www.today.com/popculture/duck-dynasty-fans-flock-west-monroe-la-8C11393570 <accessed on April 26, 2019>.

31. Amy Eley, “'Duck Dynasty’ fans flock to West Monroe, La.," Today, October 16, 2013. <accessed on April 26, 2019>.

32. "Landry Vineyards \& Winery" https://www.louisianatravel.com/agritourism/landryvineyards-winery <accessed on October 3, 2021>.

33. Hospitality Research Center, "Louisiana Tourism Forecast: 2014-2017," Prepared for Louisiana Department of Culture, Recreation and Tourism by the University of New Orleans (April 2014): 30. 34. Roger W. Riley and Carlton S. Van Doren "Movies as tourism promotion. A 'Pull' Factor in a 'Push' Location," Tourism Management (September 1992): 272.

35. "Steel Magnolias Tour of Filming Sites," https://www.natchitoches.com/listing/steelmagnolias-tour-filming-sites <accessed on September 24, 2021>.

36. California Film Commission, "California Film \& Television Tax Credit Program Guidelines," (May 2011): 2.

37. FilmL. A., Inc., “2013 Feature Film Production Report," Los Angeles, FilmL.A. Research (2014): 5. 
38. Jade L. Miller, "Louisiana Disguised: Film Tax Incentives and Location Representation in Contemporary Hollywood Films," The Journal of Popular Culture 50, no. 3 (2017): 484.

39. Mathis, "Louisiana Film Tax Credits: Costly Giveaways to Hollywood," 2.

40. Camoin Associates, Inc. "Economic and Fiscal Impact of Louisiana Entertainment Tax Credits," (2019): 9.

41. Camoin Associates, Inc. "Economic and Fiscal Impact. Motion Picture Production Tax Credit, 2019-2020," (2021): 6.

42. Camoin Associates, Inc. (2021): 4.

43. David Robb, "Film Tax Credits Get Starring Role In Louisiana Governor Race," The Deadline, June 22, 2015. https://deadline.com/2015/06/louisiana-film-tax-credits-cap-bobby-jindal-jaydardenne-1201451764/ <accessed on May 7, 2021>.

44. HR\&A Advisors, Inc., "Economic Impacts of the Louisiana Motion Picture Investor Tax Credit," 48.

45. HR\&A Advisors, Inc., "Economic Impacts of the Louisiana Motion Picture Investor Tax Credit," 36.

46. Market Dynamics Research Group (MDRG), "Louisiana Office of Tourism. Effect of Film on Visitation," Research Report (April 18, 2018: 13.

47. Market Dynamics Research Group (MDRG), "Louisiana Office of Tourism. Effect of Film on Visitation," 9.

48. Tim Morris, "Louisiana film tax credits: We know how this movie ends," NOLA.com | The Times-Picayune, October 10, 2018. https://www.nola.com/opinions/article_3cdc9e3ddcfd-5ec7-98eb-368d0073e8fd.html <accessed on May 7, 2021>.

\section{ABSTRACTS}

This paper analyses the extent to which Louisiana has Louisiana has benefited from film-induced tourism as a result of its financial efforts to lure Hollywood studios to shoot on location in the state. It also underlines the role of film offices, tourist offices and businesses in attracting movieinduced tourists. Louisiana was the pioneer state for film incentives in the USA, and the state continues to spend thousands of million dollars in tax credits. Hence, it embodies the efforts of some American states to construct a local film industry and boost movie-induced tourism.

\section{INDEX}

Keywords: Louisiana, Hollywood studios, film tax credits, film-induced tourism, shooting locations

\section{AUTHOR}

\section{JOSEPH ARMANDO SOBA}

Joseph Armando Soba is Director for international development and a research fellow in the Centre d'Études en Civilisations, Langues et Lettres Étrangères at the Université de Lille, France. 
His research explores labour relations in the American film industry as well as the internationalisation of Hollywood movies. He is the author of "Hollywood en Afrique noire : Une prédominance disputée ?" (2017); "L'étatisation du cinéma au Congo: tentative d'émancipation face aux distributeurs français et hollywoodiens (2020)"; Dans les coulisses de Hollywood. Syndicalisme et mondialisation, 1920-2012 (2020). 